\title{
Combination of the custom trays bleaching technique with the in-office bleaching and considerations for result maintenance
}

\author{
Combinação das técnicas de clareamento com moldeiras \\ customizadas e clareamento em consultório e considerações \\ para a manutenção do resultado
}

\author{
Débora MONTEIRO1 ID 0000-0002-9699-4948 \\ Adriana VIEIRA ${ }^{1}$ \\ Cláudia MAGALHÃES' ID 0000-0002-5101-8089 \\ Nelson SILVA ${ }^{1}$ \\ Rodrigo ALBUQUERQUE ${ }^{1}$
}

\section{ABSTRACT}

This study goal is to present a case report of tooth bleaching treatment with the combination of the custom tray and in-office techniques, and to discuss about the considerations for result maintenance. A treatment approach was planned involving exogenous bleaching with custom trays with $7.5 \%$ hydrogen peroxide, and in-office bleaching with $35 \%$ hydrogen peroxide. The in-office bleaching agent was applied in two 15-minute applications, without led light. The patient was instructed to use the custom trays only a day after, with one drop of the bleaching agent for each tooth space. After the application of the bleaching agent, the patient used the trays for 1 hour per day, continuously for 30 days, 15 days for each arch. Considering the executed treatment approach, we may conclude that when correctly indicated, tooth bleaching with the combination of the in-office and custom trays techniques can be an acceptable choice of treatment, capable of enhancing the smile esthetics with a simple technique that preserves the sound dental structure. The patient should be instructed for the maximum color preservation and esthetic result maintenance, and should be advised that retreatments may become necessary depending on the oral hygiene and frequence of coloured food and drinks intake.

Indexing terms: Tooth bleaching. Color. Esthetics. Hydrogen peroxide.

\section{RESUMO}

O objetivo deste estudo é apresentar um relato de caso em que foi realizado o clareamento dentário com a combinação das técnicas de consultório e de moldeiras e discutir sobre considerações para a manutenção do resultado. Um plano de tratamento foi proposto

$\boldsymbol{\nabla} \boldsymbol{\nabla} \boldsymbol{\nabla}$

1 Universidade Federal de Minas Gerais, Faculdade de Odontologia, Departamento de Odontologia Restauradora. Av. Antonio Carlos, 6627, Pampulha, 31270-901. Belo Horizonte, MG, Brasil. Correspondence to: DDH MONTEIRO. E-mail: <deborahauss@yahoo.com.br>.

$\boldsymbol{\nabla} \boldsymbol{\nabla} \boldsymbol{v}$

How to cite this article

Monteiro D, Vieira A, Magalhães C, Silva N, Albuquerque R. Combination of the custom trays bleaching technique with the in-office bleaching and considerations for result maintenance. RGO, Rev Gaúch Odontol. 2020;68:e20200003. http://dx.doi.org/10.1590/1981-8 6372020000032018-0054 
envolvendo clareamento exógeno com moldeiras com peróxido de hidrogênio 7,5\% e o clareamento em consultório com peróxido de hidrogênio 35\%. O gel clareador de clareamento em consultório foi aplicado 2 vezes, por 15 minutos cada aplicação, sem luz do tipo Led. A paciente foi orientada a usar as moldeiras customizadas para o clareamento caseiro apenas a partir do dia seguinte, sendo uma gota de gel clareador no espaço equivalente a cada dente. Após a dosagem do gel, ela usou as moldeiras por 1 hora por dia, ininterruptamente por 30 dias, sendo 15 dias para cada arco. Diante do planejamento e terapia executados no caso clínico apresentado, pode-se concluir que a técnica clareadora utilizando a combinação de clareamento em consultório e clareamento com moldeiras customizadas, quando corretamente indicada, pode ser considerada uma alternativa de tratamento bastante satisfatória por ser uma técnica simples capaz de melhorar a estética do sorriso preservando a estrutura dental hígida. O paciente deve ser orientado para a máxima preservação da cor e manutenção estética alcançada, e deve ser ressaltado que retratamentos podem ser necessários dependendo da higiene oral e da frequência de ingestão de alimentos e bebidas corantes.

Termos de indexação: Clareamento dental. Cor. Estética. Peróxido de hidrogênio.

\section{INTRODUCTION}

Tooth bleaching is a very popular esthetical treatment since it does not require any wear of the dental structure and is able to produce immediate esthetical results. Tooth color is one of the most important factors for dental appearance satisfaction [1]. Tooth bleaching consists of an oxirreduction reaction based on the partial oxydation of hydrogen peroxide; the bleaching agent modifies the dye molecule structure.

The media is a major influencer suggesting concepts regarding what is beautiful, and that is why many people seek for a esthetical treatment as a solution for the complaint regarding their teeth color. Tooth bleaching has a positive effect on self-esthetic perception and psychological impact [2]. Dentists are often questioned about the durability of bleaching results, their maintenance and also about sensitivity. The combined approach with custom trays and in office bleaching [3] can be suggested when the patient lacks discipline to use the custom trays for many days and demands a great color change, with good longevity. Choosing only in office bleaching may not lead to a stable color. Lengthening the treatment, but achieving a more stable tooth colour improves the perceived value of bleaching [4].

This study goal is to present a case report about tooth bleaching with the combination of in-office and custom tray techniques, and to discuss about the considerations for esthetical results maintenance.

\section{CASE REPORT}

A female patient, 21 years-old, was unpleased with her smile esthetics due to color (figure 1). On the clinical exam, the $A 3,5$ color was observed by direct visualization with natural light and comparison with the Classic Vita scale (Vita Zahnfabrik, Sackingen, Germany) (figure 1). There was no previous dental sensitivity and the absence of carious lesions was verified on clinical and radiographic exam. A treatment approach was planned, involving exogenous bleaching with custom trays with $7.5 \%$ hydrogen peroxide and in-office bleaching with $35 \%$ hydrogen peroxide.

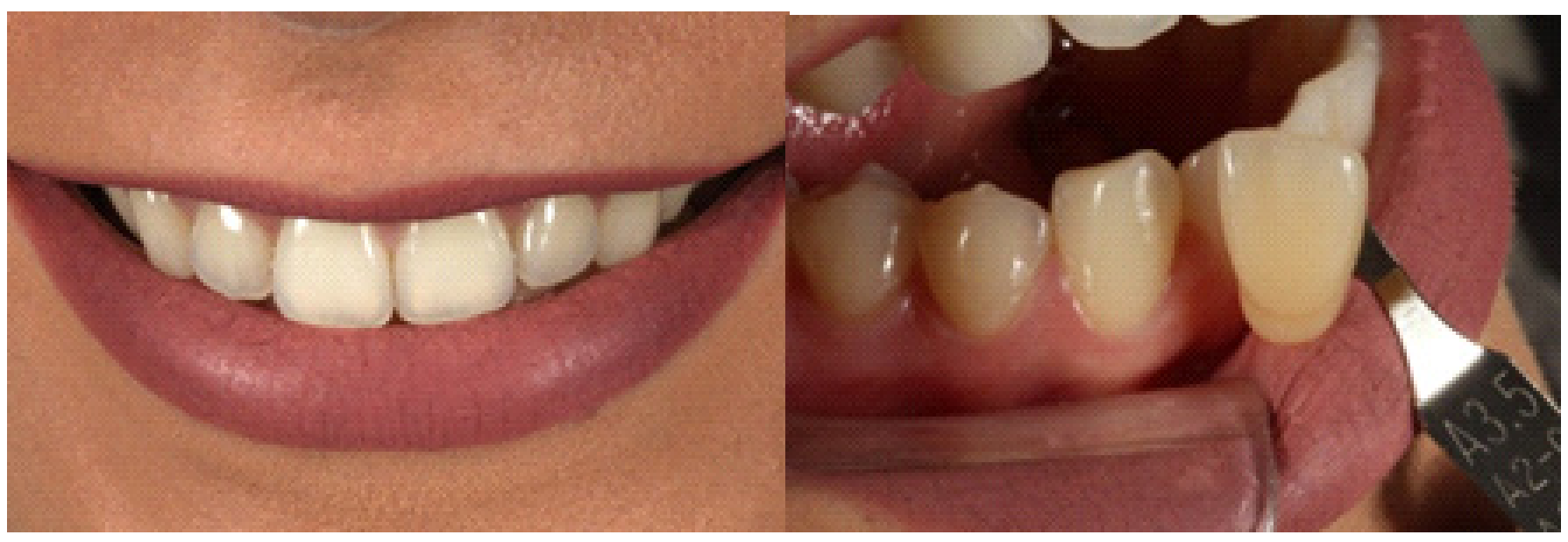

Figure 1. Before bleaching. 
For bleaching treatment beginning, the first in-office bleaching session was conducted. A labial and tongue retractor was positioned in patient's mouth and she was instructed to bite it during the procedure. The gingival barrier was applied (TopDam Blue, FGM, Joinville, Brazil) tooth to tooth (figure 2) and lightcured for 20 seconds for each two teeth. The first portion of the 35\% hydrogen peroxide bleaching agent self-mixture was disposed (Whiteness HP Maxx AutoMixx, FGM, Joinville, Brazil) and the application was done for 15 minutes without led light (figure 2). After the 15-minute period, the bleaching agent was removed from dental surface with a surgical disposable sucker in a dental vacuum pump, and another bleaching agent application was performed, the same way as the first. After the bleaching agent removal, the gingival barrier was removed and a desensitizing gel with potassium fluoride (Desensibilize KF 2\%, FGM, Joinville, Brazil) was applied on the surface for 10 minutes. After this period the desensitizing gel was removed and the dental surface was polished with a feltrum disk in a low rotation counter angle, to minimize the suface roughness. A less rough surface may tend to adhere less dyes, and the achieved resultant color may last longer.

The patient was instructed to start using the customized trays for bleaching the following day. She received oral and written instructions regarding the dosage of the $7.5 \%$ hydrogen peroxide bleaching agent (WhiteClass 7.5\%, FGM, Joinville, Brazil), which was one drop for each tooth space in the custom tray (figure 3). After the bleaching agent application in the trays, she wore them for 1 hour per day, continuously for 30 days, 15 days for each arch. The new teeth color was registered after bleaching, as described previously (figure 3). A final picture of the smile was taken, and the patient satisfaction was confirmed as a consequence of the naturality of the esthetical result. The patient signed an informed consent form.

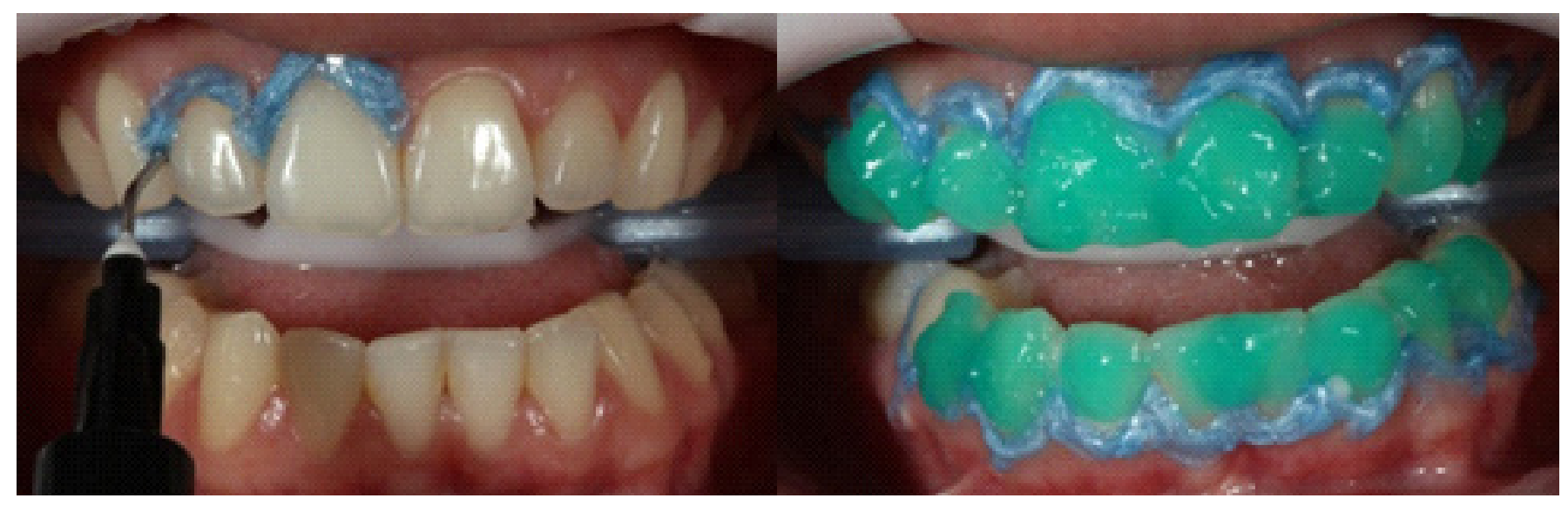

Figure 2. Gingival barrier application and tooth bleaching.

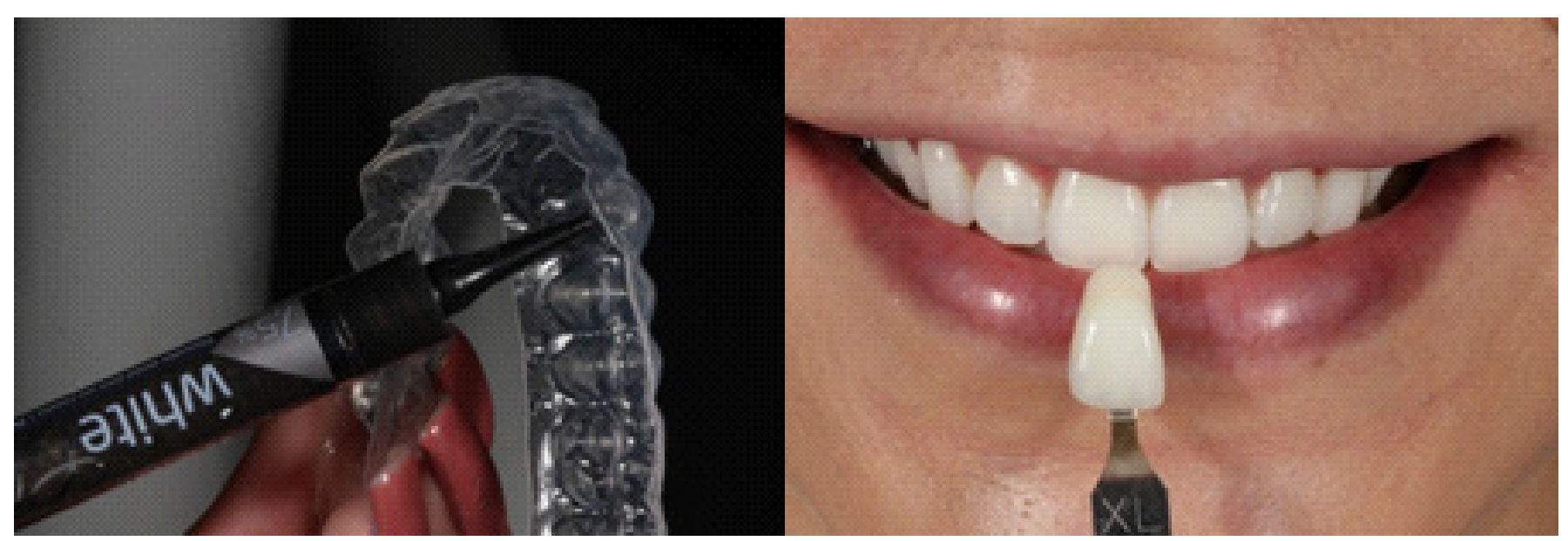

Figure 3. Bleaching agent in the tray and bleaching result. 


\section{DISCUSSION}

The beauty concept may be influenced by the personal experiences, media and society. The individual satisfaction at the end of an esthetical dental treatment depends on the technical and scientific quality of the procedures, but also on the coincidence between patient expectations and professional goals. The appearance and color of teeth are a common concern for patients and are associated with an increased desire for treatments that improve dental aesthetics, including tooth whitening [5]. The dental clinicians are responsible for the esthetical correction of size, shape, color and position alterations, which are very often in daily clinics.

Tooth bleaching treatment with 35\% hydrogen peroxide is more effective than $15 \%$ hydrogen peroxide, but generates a greater risk and intensity of tooth sensitivity [6]. However, in-office bleaching could be considered an effective method for adolescents and young adults [7]. Different concentrations during the same application time of at-home bleaching achieved similar results [8]. In this case report, we used the combined technique to achieve an effective and faster result, aiming better hypersensitivity control. The combined approach with custom trays and in-office bleaching [3] should be an option when the professional realizes that the patient has a difficult daily routine that could slow up the result and is not motivated to use the custom trays for many days. Using only the inoffice bleaching technique may lead to a faster bleaching but with higher sensitivity [9] and a less stable resultant color. And if the patient is seeking for a high color change with the best possible longevity, making the treatment go on slower could be necessary, since achieving a stable color is important [4]. So, the combination of techniques seemed suitable for the case reported, due to patient demands.

Tooth bleaching is not associated to visible damage to dental tissues; however, there are concerns about the enamel surface alterations, mainly with in-office bleaching, since the bleaching agent is more concentrated. Hydrogen peroxide $37.5 \%$ produces morphological changes and calcium and phosphorus decrease, while $16 \%$ carbamide peroxide produces no morphological changes, and the decrease in mineral component is smaller [10]. Hydrogen peroxide concentration above $15 \%$ does not increase bleaching effectiveness, and may increase the possibility of alteration of enamel hardness, surface morphology, and acidity of the medium [11]. In-office bleaching with $40 \%$ hydrogen peroxide could be considered at least as safe as home bleaching, as far as their effects on human enamel are concerned [12]. However, human saliva is probably able to decrease this enamel demineralization, as it exherts the same effect of some surface treatments such as fluoride and CPP-ACPF complex [13]. So, with in-office bleaching, the mineral loss after bleaching is progressively reverted by human saliva contact [14].

Bleached enamel stains more than non bleached when in contact with a dying beverage and this discolouration is more evident right after bleaching treatment; the dyes absorption by the enamel treated with Whiteness HP Maxx is smaller after 1 week than immediately after bleaching [15]. However, considering the daily exposure to coffee during enamel remineralization after bleaching, other authors suggest that avoiding coffee consumption immediately after bleaching is not necessary [14].

Submitting teeth and oral tissues to a low or high $\mathrm{pH}$ agent for a long period of time may cause some adverse effects. In this case report, the chosen bleaching agent for custom trays has an almost neutral $\mathrm{pH}$. The agent for the in-office bleaching is neutral and maintain its stability during the application time, as suggested by the manufacturer. The activation of in-office bleaching gel with light does not improve color change or affect tooth sensitivity, regardless of the hydrogen peroxide concentration [16]. There was no light application for in-office bleaching in this case report.

Materials with higher concentrations of bleaching agent demonstrate greater bleaching effectiveness but also greater hypersensitivity. Desensitizing agents were used after in-office bleaching in this case report to reduce the hyperalgesia symptom, avoiding pain after treatment, as described elsewhere [17]. Lengthening the treatment process, but achieving a more stable tooth colour may improve the perceived value of the bleaching treatment [4]. The enamel remineralization makes the dye absorption difficult, which enhances bleaching result maintenance, due to better stability of color. The exogenous bleaching agents were chosen because they had calcium ions in their formulae, to minimize the alterations of the dental enamel and to collaborate as a desensitizer, as recommended by the manufacturer. The addition of calcium contributes to a reduction in tooth sensitivity, especially with a low concentration of hydrogen peroxide [7]. A good oral hygiene is also fundamental for color maintenance, since it removes the teeth extrinsic pigmentation induced by 
food and beverages dyes. It is also important to instruct patients to avoid the intake of coloured food and drinks anyway. They need to know that the resultant color is not permanent $[18,19]$ and the treatment repetition may be necessary some day. The tooth structure reorganizes itself within the years, in accordance with dyes penetration and hygiene habits to remove extrinsic pigmentation [20]. That is the reason that the moment of need of bleaching repetition is not the same for everyone, when the goal is the color maintenance.

For any clinical situation it is important to choose the more conservative treatment approach to assure an esthetically satisfying result with the greater possible preservation of the dental structure.

\section{CONCLUSION}

Considering the executed treatment approach, we may conclude that when correctly indicated, tooth bleaching with the combination of the in-office and custom trays techniques can be an acceptable choice of treatment, capable of enhancing the smile esthetics with a simple technique that preserves the sound dental structure. The patient should be oriented for the maximum color preservation and esthetic result maintenance, and should be advised that retreatments may become necessary depending on the oral hygiene and frequence of coloured food and drinks intake.

\section{Collaborators}

D MONTEIRO, contribution to the treatment plan design, revision of the manuscript, contribution to acquisition and interpretation of the pictures, sketch of the paper, final approval of the version to the published and agreement on being responsible for the integrity of the report. A VIEIRA, contribution to acquisition and interpretation of the pictures, sketch of the paper, final approval of the version to the published and agreement on being responsible for the integrity of the report. C MAGALHÃES, contribution to the conception of treatment plan; acquisition, analysis and interpretation of the pictures and other data; sketch of the paper, final approval of the version to the published and agreement on being responsible for the integrity of the report. N SILVA, contribution to the conception of treatment plan; analysis and interpretation of the data; intelectually critical revision of the manuscript, final approval of the version to the published and agreement on being responsible for the integrity of the report. R ALBUQUERQUE, contribution to the conception of treatment plan and treatment plan design, interpretation of the data; intelectually critical revision of the manuscript, final approval of the version to the published and agreement on being responsible for the integrity of the report.

\section{REFERENCES}

1. Yu H, Cheng SL, Zhou JY, Cheng $H$. A survey on general knowledge and influencing factors of dental aesthetics among three universities students in Fuzhou city. Shanghai Kou Qiang Yi Xue. 2017;26(5):510-15.

2. Bersezio C, Martin J, Peña F, Rubio M, Estay J, Vernal $R$, et al. Effectiveness and impact of the walking bleach technique on esthetic self-perception and psychosocial factors: a randomized Double-blind clinical trial. Oper Dent. 2017;42(6):596-605. http://dx. doi.org/10.2341/16-133-C

3. Izidoro ACSA, Martins GC, Higashi C, Zander-Grande C, Tay $L Y$, Gomes $J C$ et al. Combined technique for bleaching non-vital teeth with 6-month clinical follow-up: case report. Int J Oral Dent Health. 2015;1:2,1-4.

4. Klaric Sever E, Budimir Z, Cerovac M, Stambuk M, Par M, Negovetic Vranic D, et al. Clinical and patient reported outcomes of bleaching effectiveness. Acta Odontol Scand. 2018; 76(1):30-8. http://dx.doi.org/10.1080/00016357.2017. 1376111

5. Joiner A, Luo W. Tooth colour and whiteness: a review. J Dent. 2017;67S:S3-S10. http://dx.doi.org/10.1016/j.jdent.2017. 09.006

6. Lima SNL, Ribeiro IS, Grisotto MA, Fernandes ES, Hass V, de Jesus Tavarez RR, et al. Evaluation of several clinical parameters after bleaching with hydrogen peroxide at different concentrations: a randomized clinical trial. J Dent. 2018;68:91-97. http://dx.doi.org/10.1016/j.jdent.2017.11.008

7. Gonçalves MLL, Tavares ACDS, Mota ACCD, Penna LAP, Deana AM, Bussadori SK. In-office tooth bleaching for adolescents using hydrogen-peroxide-based gels: clinical trial. Braz Dent J. 2017;28(6):720-25. http://dx.doi.org/10.1590/0103-6440 201701516

8. López Darriba I, Novoa L, de la Peña VA. Efficacy of different protocols for at-home bleaching: a randomized clinical trial. Am J Dent. 2017;30(6):329-34.

9. Mondelli RFL, Azevedo JFDG, Francisconi AC, Almeida CM, Ishikiriama SK. Comparative clinical study of the effectiveness of different dental bleaching methods - two year follow-up. J Appl Oral Sci. 2012; 20(4):435-43.

10. Llena C, Esteve I, Forner L. Effect of hydrogen and carbamide peroxide in bleaching, enamel morphology, and mineral composition: in vitro study. J Contemp Dent Pract. 2017;18(7):576-82.

11. Grazioli G, Valente LL, Isolan CP, Pinheiro HA, Duarte CG, Münchow EA. Bleaching and enamel surface interactions resulting from the use of highly-concentrated bleaching gels. Arch Oral Biol. 2017;87:157-62. http://dx.doi.org/10.1016/j. archoralbio.2017.12.026 
12. Polydorou O, Scheitza S, Spraul M, Vach K, Hellwig E. The effect of long-term use of tooth bleaching products on the human enamel surface. Odontology. 2018;106(1):64-72. http://dx.doi.org/10.1007/s10266-017-0308-3

13. Monteiro D, Moreira A, Cornacchia T, Magalhães C. Evaluation of the effect of different enamel surface treatments and waiting times on the staining prevention after bleaching. J Clin Exp Dent. 2017;9(5):e677-81. http://dx.doi.org/10.4317/ jced. 53712

14. Sa Y, Chen D, Liu Y, Wen W, Xu M, Jiang T, et al. Effects of two in-office bleaching agents with different $\mathrm{pH}$ values on enamel surface structure and color: an in situ vs. in vitro study. J Dent. 2012;40(Suppl 1):e26-34. http://dx.doi.org/10.1016/j. jdent.2012.02.010

15. Mori AA, Lima FF, Benetti AR, Terada RSS, Fujimaki $M$, Pascotto RC. Susceptibility to coffee staining during enamel remineralization following the in-office bleaching technique: an in situ assessment. J Esthet Restor Dent. 2015:1-9. http:// dx.doi.org/10.1111/jerd.12134

16. Maran BM, Burey A, de Paris Matos T, Loguercio AD, Reis A. In-office dental bleaching with light vs. without light: a systematic review and meta-analysis. J Dent. 2017; S0300-
5712(17)30283-X. http://dx.doi.org/10.1016/j.jdent.2017.11. 007

17. De Paula B, Alencar C, Ortiz M, Couto R, Araújo J, Silva C. Effect of photobiomodulation with low-level laser therapy combined with potassium nitrate on controlling postbleaching tooth sensitivity: clinical, randomized, controlled, double-blind, and split-mouth study. Clin Oral Investig. 2018; Oct 25, http://dx.doi.org/10.1007/s00784-018-2715-4.

18. Al-Tarakemah Y, Darvell BW. On the permanence of tooth bleaching. Dent Mater. 2016; 32(10):1281-8. http://dx.doi. org/10.1016/j.dental.2016.07.008

19. Bacaksiz A, Tulunoglu O, Tulunoglu I. Efficacy and stability of two in-office bleaching agents in adolescents: 12 months follow-up. J Clin Pediatr Dent. 2016; 40(4):269-73. http://dx. doi.org/10.17796/1053-4628-40.4.269

20. de Geus JL, de Lara MB, Hanzen TA, Fernández E, Loguercio $A D$, Kossatz $S$, Reis $A$. One-year follow-up of at-home bleaching in smokers before and after dental prophylaxis. J Dent. 2015; 43(11):1346-51. http://dx.doi.org/10.1016/j.jdent. 2015.08.009

Received on: 4/2/2019 Approved on: 15/2/2019 